\title{
Simulating the Long-term Response of Tropical Wet Forests to Fragmentation
}

\author{
Peter Köhler, ${ }^{1 *}$ Jérôme Chave, ${ }^{2}$ Bernard Riéra, ${ }^{3}$ and Andreas Huth ${ }^{4}$
}

\begin{abstract}
${ }^{1}$ Center for Environmental Systems Research, University of Kassel, Kurt-Wolters-Strasse 3, D-34109 Kassel, Germany; ${ }^{2}$ Department of Ecology and Evolutionary Biology, Guyot Hall, Princeton University, Princeton, New Jersey 08544-1003, USA; ${ }^{3}$ Laboratoire d'Ecologie Générale, CNRS-MNHN, UMR 8571, 4 avenue du Petit Château, 91800 Brunoy, France; and ${ }^{4}$ Center for Environmental Research Leipzig-Halle, Department of Ecological Modeling, P.O. Box 500 136, D-04301 Leipzig, Germany
\end{abstract}

\begin{abstract}
In the coming decades, a large fraction of the world's tropical forests will be fragmented into remnants surrounded by secondary vegetation, landuse areas, or roads. It is important to develop integrative tools to monitor the evolution of these fragmented ecosystems. We used the individualoriented and process-based forest growth simulator Formind 2.0 to investigate the spatial and temporal effects on standing biomass and functional diversity of various intensities and patterns of fragmentation within a forest landscape. The simulator was calibrated for an old-growth wet forest in French Guiana, South America. We found that the standing biomass of forest remnants was reduced significantly compared to a similar area of nonfragmented
\end{abstract}

forest. When fewer but larger remnants were created rather than many small ones, the total loss in biomass and the increase in the abundance of earlysuccessional species were significantly reduced, confirming that edge effects dominate the functioning of forest remnants. We also performed simulations of secondary succession after the landscape had been abandoned. The simulated recovery time in those secondary forests depends on both the size of cleared area and the spatial pattern of the remnant forests.

Key words: edge effects; fragmentation; French Guiana; forest growth model; tropical forest; secondary succession; spatially explicit simulation.

\section{INTRODUCTION}

Tropical forests cover only $7 \%$ of the Earth, yet they represent $50 \%$ of the aboveground terrestrial carbon pool and as much as 70\% of the planet's species richness. However, this type of ecosystem is now undergoing rapid degradation. Tropical deforestation figures have hovered around 1\% per year, on average, over the past 30 years (FAO 1997). Thus, it is generally agreed that in the near future, large areas of tropical forests will become fragmented and

Received 30 January 2002; accepted 16 July 2002.

*Corresponding author's current address: Alfred Wegener Institute for Polar and Marine Research, P.O. Box 1201 61, D-27515 Bremerhaven, Germany; e-mail: pkoehler@awi-bremerhaven.de

Current address for J. Chave: Laboratoire d'Ecologie Terrestre, CNRS, UMR 5552, 13 avenue Colonel Roche, BP 4072, F31029 Toulouse, France exist only as remnants within a managed or degraded landscape. Even if efficient conservation programs could be set up quickly, nonprotected areas would likely continue to be degraded at a rapid pace. Therefore, it is imperative that restoration programs based on a firm knowledge of the ecology of fragmented forests be developed (for reviews, see Saunders and others 1991; Murcia 1995; Brown and Lugo 1990).

The ongoing functional alterations in fragmented forests have recently been quantified in field studies. For example, fragmentation modifies microclimatic conditions, and these changes appear to lead to the increased mortality of emergent trees (Nepstad and others 1999; Laurance and others 2000). At the same time, the age structure of animal populations becomes altered (Woodroffe and Ginsberg 
1998; Curran and others 1999; da Silva and Tabarelli 2000), and these changes can feed back into vegetation processes due to changes in seed dispersal and predation and herbivory intensities (Laurance and Bierregaard 1997). Ferreira and Laurance (1997) showed that in forest fragments of 1000 ha, $22 \%-42 \%$ of the area is actually influenced by edges. Laurance and Yensen (1991) used a theoretical framework to suggest that even large forest fragments could be dominated by edge effects. According to their analysis, significant edge effects would be observed even for fragments as large as 500 ha. Chave and others (2002) used a model of plant diversity to investigate the effects of fragmentation on the maintenance of diversity in a community of trees. However useful it is to quantify some of the consequences of fragmentation on tropical forest functioning, we argue that these analyses are not sufficient to assess the full consequences of forest fragmentation on standing biomass and functional diversity.

Indeed, predicting the fate of a fragmented forest landscape over more than a few decades remains a challenging task. There is no doubt that forests can encroach rapidly on clear-cut areas, but the challenge is to understand how fast they will be able to return to a structural equilibrium (Saldarriaga and others 1988; Brown and Lugo 1990), or even to a species composition characteristic of a mature tropical forest (Finegan 1996). Moreover, the dynamics of succession depend strongly on the type of disturbance, on soil impoverishment (Uhl and others 1988; Aide and others 1995), and on the landscape structure (Purata 1986; Kramer 1997; Helmer 2000). Although we need more detailed long-term assessments, we suggest here that our current knowledge needs to be mustered into a modeling approach to relate the recent findings of field ecology to conservation issues (Kremen and others 2000). So far, there has been little attempt to include this knowledge into a process-based simulator for tropical forests (Liu and Ashton 1998).

In recent years, new types of forest growth simulators have been developed that rely on classic gap model approaches (Botkin 1993; Shugart 1998) but include spatially explicit and process-based descriptions of tree growth (Pacala and others 1996). Such models have recently been developed for mature tropical forests (Köhler and Huth 1998; Chave 1999b) and should allow for the quantification of disturbance impacts on forest variables. These models should also help to disentangle the relative impacts of natural forest regeneration and fragmentation. Recently, a similar strategy was used to model long-term changes of forest landscapes in the state of Wisconsin (He and Mladenoff 1999).

In this paper, we provide the first analysis of this type for tropical forests. Our approach uses the previously developed process-based forest growth model Formind (Köhler and Huth 1998). This model describes the spatiotemporal dynamics of a mixed forest stand for an area up to several square kilometers based on a carbon cycle model for different plant functional types. In Formind, individual trees compete for light and space, and seed dispersal as well as gap formation are modeled in detail. The model has been applied to the tropical forests of Malaysia (Köhler and others 2001; P. Köhler and A. Huth unpublished) and Venezuela (Kammesheidt and others 2001) to address forest management issues, such as the long-term impacts of logging on forest dynamics. Here we address the issue of fragmentation with a new parameterization of our model for a wet forest in French Guiana. We then assess the generality of our results across forests.

We focus on the influence of the intensity and the pattern of forest clearing in a $1 \mathrm{~km}^{2}$ landscape. In particular, we address the following questions: (a) How are the standing biomass, species composition, and size structure of forest remnants altered by different forest-clearing scenarios? (b) What functional type will be dominant on these cleared areas in a secondary succession?

\section{METHODS}

\section{Study Area}

The forest of French Guiana is one of the best protected in South America due to low anthropogenic pressure and high labor costs that have made this forest unattractive for logging companies. French Guiana lies between $2^{\circ} 10^{\prime}$ and $5^{\circ} 45^{\prime} \mathrm{N}$ and $51^{\circ} 40^{\prime}$ and $54^{\circ} 30^{\prime} \mathrm{W}$ in northeastern South America. The region is almost completely covered with lowland tropical forest. Annual rainfall is between 2000 and $4000 \mathrm{~mm}$, with a decreasing gradient from the coastal area southeastward. A pronounced dry season of 2 months occurs from September to November and a shorter dry season in March. The average temperature is $25.8^{\circ} \mathrm{C}$, with an annual amplitude of $2^{\circ} \mathrm{C}$ and daily amplitudes of $7^{\circ} \mathrm{C}$ in the rainy season $\left(10^{\circ} \mathrm{C}\right.$ during the dry season). The geology is typical of the Guiana Shield, with a central pediplain and sparse rugged mountains of Precambrian metamorphic and granitic rocks.

The Piste de Saint-Elie Research Station $\left(5^{\circ} 30^{\prime} \mathrm{N}\right.$, $\left.53^{\circ} 00^{\prime} \mathrm{W}\right)$, located $16 \mathrm{~km}$ south of Sinnamary, has been much studied since 1976 (Lescure and others 
1983; Lescure and Boulet 1985; Puig and others 1990; Pelissier and Riéra 1993). Annual rainfall is slightly above $3000 \mathrm{~mm} \mathrm{y}^{-1}$; altitude is approximately $50 \mathrm{~m}$ a.s.l. This forest grows mostly on a schist mantle covered by a sandy clayey soil (Lescure and Boulet 1985). Dominant tree families are Lecythidaceae, Caesalpiniaceae, and Chrysobalanaceae (Mori 1989; Puig and others 1990; Poncy and others 2000). A 5-ha forest inventory, where all 2740 trees $10 \mathrm{~cm}$ or greater in diameter at breast height (dbh) have been tagged, measured, and mapped, was used for this study. A total of 261 species were found in a sample of 2475 individuals (B. Riéra unpublished). The average basal area was $30.2 \mathrm{~m}^{2} \mathrm{ha}^{-1}$. The 5-ha plot is part of the larger forest tract, and it spans a broad range of soil and drainage types (Sabatier and others 1997; Molino and Sabatier 2001). A variety of soil and drainage types are encountered at Piste de Saint-Elie, yet the number of species restricted to specific environments is limited, although abundance shifts can be observed along an environmental gradient among species in the same family (Sabatier and others 1997).

\section{The Model}

FORMIND2.0 is an individual-oriented (Uchmański and Grimm 1996) and process-based forest growth model that simulates the spatial and temporal dynamics of uneven-aged mixed forest stands. A complete model description has already been published (Köhler and Huth 1998; Köhler 2000; Kammesheidt and others 2001). An overview of the important functions and parameters of Formind2.0 is presented in the Appendix.

Formind2.0 describes a forest stand as a mosaic of patches of $20 \times 20 \mathrm{~m}$ in size. Patches interact through seed dispersal, treefall events, and shading. Within patches, trees are not distributed in a spatially explicit fashion; thus, competition for light and space follows the gap modeling approach (Botkin 1993; Liu and Ashton 1995; Shugart 1998; Bugmann and Solomon 2000). The vertical light profile within the canopy is deduced from the distribution of the tree crowns. The carbon balance of individual trees is modeled by including the main physiological processes (photosynthesis, respiration). Growth process equations and physiological parameters are the same as in the related model Formix3-Q (Ditzer and others 2000). Allometric relationships relate the aboveground biomass, stem diameter, tree height, and crown diameter (see Appendix). Tree mortality can occur either through self-thinning in dense patches, senescence, or large treefalls (gap formation).
Seed production by reproductive trees (in the model, trees above a group-specific threshold) is correlated with the reproductive success at a dbh equal to $1 \mathrm{~cm}$ (Nathan and Muller-Landau 2000). In the model, the rate of seed production encompasses several regeneration stages: fecundity, seed survival, germination, and possible predation upon seedlings smaller than $1 \mathrm{~cm}$ dbh (Chave 1999b). The general approach of lumping different recruitment stages was compared with field data in a model application in a rain forest in Sabah, Malaysia (Curran and others 1999; P. Köhler and A. Huth unpublished). Empirical figures matched the chosen recruitment rates for reproductive success.

Seed dispersal is a complex process that includes primary dispersal by gravity or wind, followed by secondary dispersal events by water or animals (Chambers and MacMahon 1994). Our approach is spatially explicit: Seeds are dispersed according to a predefined seed shadow that we here take to be a Gaussian distribution. The direction of seed dispersal is chosen randomly (see the review of dispersal models in Clark and others 1999). This strategy has also been used to model the influence of limited seed dispersal on the landscape-scale dynamics of a temperate forest (He and Mladenoff 1999).

\section{Species Grouping, Parameterization, and Initialization}

We constructed a species list covering over a thousand tree and shrub species found in French Guiana (Chave 1999a), extending the work of Favrichon (1994) and using the data of van Roosmalen (1985) and additional information; we defined 19 plant functional types (PFTs) based on successional status and maximum tree height at maturity (Table 1). A complete species list is available from the authors on request. Tree species groupings of this type have already been described for a rain forest community in Sabah, Malaysia (Köhler and others 2000). We considered three classes of successional types: early-, mid-, and late-successional species, and five classes of maximum tree height. We classified the species into shrubs $(0-5 \mathrm{~m})$, understorey $(5-15 \mathrm{~m})$, lower canopy (15-25 m), upper canopy (25-36 m), and emergents (over $36 \mathrm{~m}$ ), similar to the grouping of Sabah's rain forest species. In addition, the species list contains savanna species that are classified as full light-demanding.

An earlier case study in French Guiana provided model parameter values (Chave 1999b) (see Appendix). A regression relating tree height to trunk diameter, irrespective of species, was derived by Gazel (1983). Other allometric relations (for exam- 
Table 1. Tree Species Grouping in Plant Functional Types

\begin{tabular}{|c|c|c|c|c|c|c|}
\hline Plant Functional Type & $\begin{array}{l}\text { Height } \\
\text { (m) }\end{array}$ & PFT & SS & HG & No & $\begin{array}{l}\mathrm{Ab} \\
(\%)\end{array}$ \\
\hline Shrub savanna spp. & $\leq 5$ & 1 & 0 & 1 & 7 & 0.0 \\
\hline Shrub early-successional spp. & $\leq 5$ & 2 & 1 & 1 & 17 & 0.1 \\
\hline Shrub midsuccessional spp. & $\leq 5$ & 3 & 2 & 1 & 29 & 1.0 \\
\hline Shrub late-successional spp. & $\leq 5$ & 4 & 3 & 1 & 83 & 2.0 \\
\hline Understorey savanna spp. & $5-15$ & 5 & 0 & 2 & 31 & 0.0 \\
\hline Understorey early-successional spp. & $5-15$ & 6 & 1 & 2 & 74 & 1.4 \\
\hline Understorey midsuccessional spp. & $5-15$ & 7 & 2 & 2 & 76 & 3.5 \\
\hline Understorey late-successional spp. & $5-15$ & 8 & 3 & 2 & 152 & 5.4 \\
\hline Lower canopy savanna spp. & $15-25$ & 9 & 0 & 3 & 7 & 0.0 \\
\hline Lower canopy early-successional spp. & $15-25$ & 10 & 1 & 3 & 48 & 2.8 \\
\hline Lower canopy midsuccessional spp. & $15-25$ & 11 & 2 & 3 & 84 & 11.4 \\
\hline Lower canopy late-successional spp. & $15-25$ & 12 & 3 & 3 & 122 & 18.1 \\
\hline Upper canopy savanna spp. & $25-36$ & 13 & 0 & 4 & 2 & 0.0 \\
\hline Upper canopy early-successional spp. & $25-36$ & 14 & 1 & 4 & 38 & 1.6 \\
\hline Upper canopy midsuccessional spp. & $25-36$ & 15 & 2 & 4 & 67 & 22.2 \\
\hline Upper canopy late-successional spp. & $25-36$ & 16 & 3 & 4 & 103 & 21.0 \\
\hline Emergent early-successional spp. & $>36$ & 17 & 1 & 5 & 12 & 0.9 \\
\hline Emergent midsuccessional spp. & $>36$ & 18 & 2 & 5 & 38 & 6.4 \\
\hline Emergent late-successional spp. & $>36$ & 19 & 3 & 5 & 32 & 2.2 \\
\hline
\end{tabular}

Autecological characteristics of 19 plant functional types (PFT) of French Guiana's tropical forest tree species. Height at maturity. SS: successional status. HG: height group. No: Number of species per PFT. Ab: Abundance of trees with dbh $\geq 10 \mathrm{~cm}$ in research plots in Nouragues (from the AUBLET database), Piste de Saint-Elie, and Paracou (from Favrichon 1994).

ple, leaf and crown area to diameter ratios) are taken from Kato and others (1978) and Kira (1978), who studied the Pasoh forest reserve in peninsular Malaysia. This leads to an average leaf area index for the canopy of about $6 \mathrm{~m}^{2} \mathrm{~m}^{-2}$ at our site. The photosynthetic response of PFTs to different light levels is taken from Oberbauer and Strain (1984). The wood density of PFTs was deduced from a literature survey. Parameters for respiration processes $\left(r_{0 s}\right.$ and $\left.r_{1 s}\right)$ were investigated using parameter variation to gain realistic diameter increment values for different size classes and light conditions (see also Gourlet-Fleury and Houllier 2000). This comparison with field data validates our parameterization of the individual tree growth model and the light competition processes. Mortality and ingrowth rates correspond to typical values found in the literature (Phillips and Gentry 1994; Condit and others 1995a, 1995b; van der Meer and Bongers 1996). We hypothesized that mortality rate $M$ is correlated to the diameter growth rate $g_{\mathrm{d}}$ and maximum attainable dbh $d_{\max }$ so that the dimensionless number $\omega=d_{\max } / g_{\mathrm{d}} \cdot M$ is roughly invariant among PFTs and is close to one. This condition ensures that the abundance of the larger size classes is not too large $(\omega \ll 1)$ or too low $(\omega \gg 1)$ (Chave 1999b). High mortality rates of small-sized PFTs is consistent with available data (Condit and others 1995b). The sensitivity of the model to parameter variations has been investigated in detail elsewhere (Köhler 2000; Kammesheidt and others 2001; P. Köhler and A. Huth unpublished). To generate a reasonable initial condition, we ran the model with the 5-ha inventory (only trees with a dbh of at least $10 \mathrm{~cm}$ ). This calculation generated the stem-dbh distribution of a demographically stable forest with characteristics similar to the field data, which was then used as the initial condition for our simulations.

In empirical studies, it was found that tree mortality increases at the edge of forest remnants (Gascon and others 2000). Indeed, fragmentation results in microclimatic changes and enhances the effect of wind turbulence. A long-term study near Manaus, Brazil, further found that emergent trees (dbh of at least $60 \mathrm{~cm}$ ) are disproportionately sensitive to edge effects (Laurance and others 1998, 2000; Mesquita and others 1999). The type of vegetation surrounding the fragments had varying effects on tree mortality (Mesquita and others 1999). We modeled this phenomenon by assuming that trees within $100 \mathrm{~m}$ from the edges had an increased risk of death. Tree mortality rates depend explicitly on the distance from the nearest forest edge, the type of surrounding vegetation, and tree size (Figure 1). A similar 


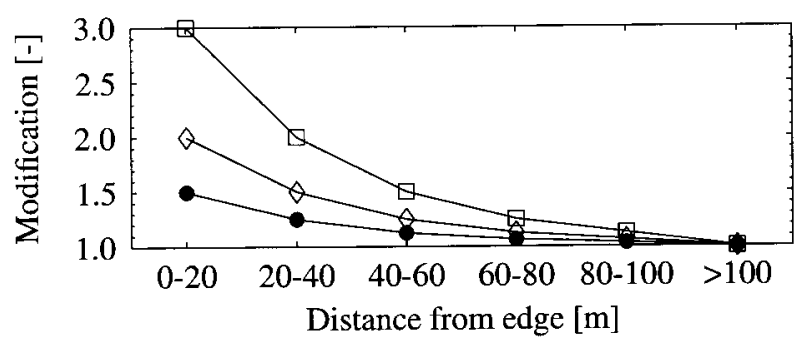

Figure 1. Modification factor of tree mortality rates at forest edges. We distinguish between forest edges near cleared areas (open markers: large trees with $\mathrm{dbh} \geq 60 \mathrm{~cm}$ $[\square]$ and others $[\diamond])$ and forests in the neighborhood of regrowth for the first 20 years of the secondary succession (O). Mortality rates for trees beyond $100 \mathrm{~m}$ from the edge were not modified. All distances between patches were computed from their centers. The correction factors were calibrated by field studies undertaken in the central Amazon tropical forest (Laurance and others 1998, 2000; Mesquita and others 1999).

approach was followed in a previous model of the changes of a forested landscape in the Republic of Congo (Wilkie and Finn 1988).

\section{Scenarios}

We studied the spatiotemporal dynamics of fragmented landscapes to assess the simulated longterm impact of fragmentation on forest dynamics, including (a) the impacts of fragmentation on forest remnants and (b) the growth of secondary forest within the landscape.

Fragmentation. Within a landscape of $1 \mathrm{~km}^{2}$, we assumed that a percentage $C F$ of the total area was cleared and converted into nonforest areas $(C F=$ $0 \%$ to $90 \%$, values of $C F$ every $10 \%$ ). Large clearings were composed of smaller units that had a minimum size of 1 ha and were square in shape. The nutrient budgets of the abandoned areas were kept constant and uniform. Different patterns of fragmentation were investigated. The null model of fragmentation (Fahrig 1992), which consists of clearing patches at random, was compared with simulations in which the cleared patches were spatially correlated. Spatial correlations are meant to mimic more realistic fragmentation scenarios, in which clear-cut patches are not randomly placed in space (for a mathematical description of spatial correlation for disturbance regimes, see Moloney and Levin 1996). This spatial correlation led to clustered structures of the remnant forests. We investigated the random fragmentation scenario and three different clustering intensities. Here we report the results only of the random fragmentation scenario and the scenario with maximal spatial clustering, together with three of nine fragmentation intensities (measured by the percentage $C F$ ).

Secondary succession. In the same simulations, after 300 simulated years of fragmentation, we assumed that the land-use areas were abandoned. Secondary forest succession was investigated for another 300 years. For those scenarios, the modified mortality rates at the forest edges were independent of tree size and restricted to the first 20 years of the secondary succession. This approach follows the results of Mesquita and others (1999), where edge-effected mortality rates depend on the neighboring vegetation (Figure 1).

The simulations were carried out with the full model, including 19 PFTs, but simple indicators are necessary to interpret the results. We used three indicators to track the various effects of the fragmentation experiment on a pristine forest. We monitored (a) the standing aboveground biomass, (b) the percentage of total biomass of early-versus late-successional species, and (c) the spatial distribution of large trees in fragmented landscapes.

\section{Statistics}

We used analysis of variance (ANOVA) to look for significant differences between the results of the simulation scenarios. ANOVA was restricted to the special case with one replicate simulation $(n=1)$ (Graf and others 1987). Thus, only the main effects of the scenarios were analyzed, and not the interactive effects. This was justified according to our former model analysis, from which we know that the simulation results depend weakly on stochastic events if scenarios similar to those proposed here were analyzed (Köhler 2000).

\section{RESULTS}

We focus first on the effects on the remaining forests when partial forest clearing is induced by increasing the edges. Then we investigate the vegetation structure that results when secondary forest invades abandoned lands.

\section{Effects of Clearing on Forest Remnants}

In our control run without forest clearing, the simulated forest site supported $445 \mathrm{Mg} \mathrm{ha}{ }^{-1}$ of aboveground biomass, partitioned into $4 \%$ earlysuccessional PFTs and 53\% late-successional PFTs $(C F=0 \%$ in Figure 2).

With increasing fragmentation intensity, the standing biomass decreased and the biomass in early-successional PFTs increased, both significantly 


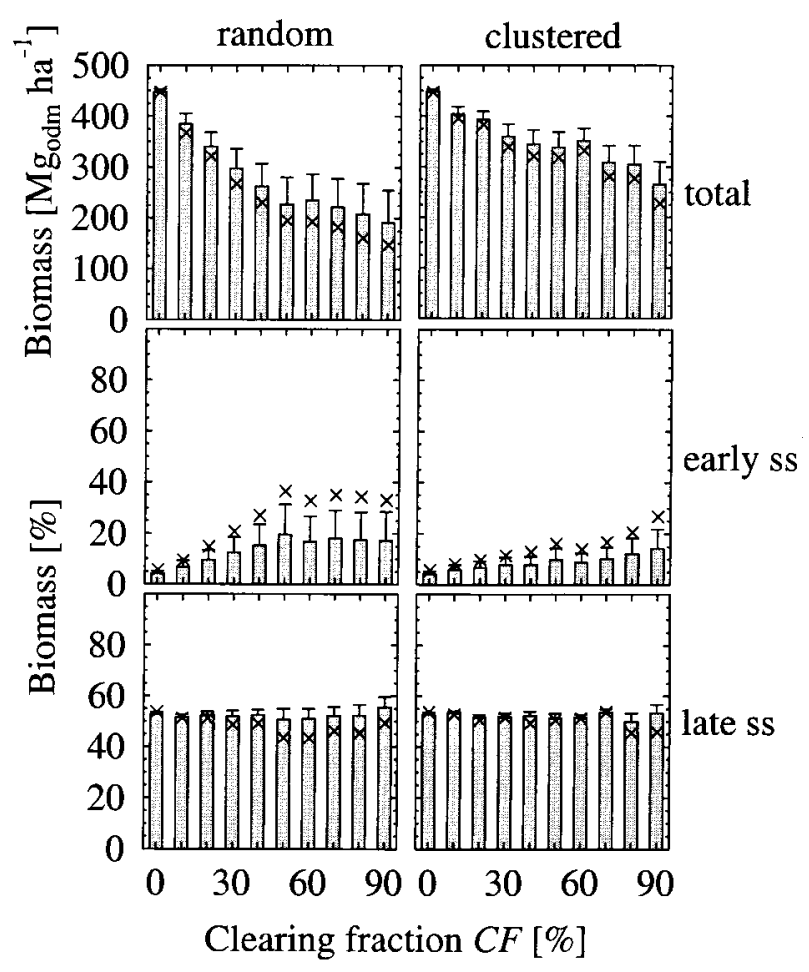

Figure 2. Forest dynamics in a partially fragmented landscape $(t=0-300 \mathrm{y})$. Aboveground biomass as a function of cleared fraction $(C F)$ and pattern formation (random versus clustered). Bars show time averages (including $\mathrm{SD})$; crosses correspond to values at $t=300 \mathrm{y}$. Total biomass in organic dry matter (1st row) and fraction of early- and late-successional species (2nd and 3rd row).

$(P<0.001)$. In the random fragmentation scenario, both the biomass and percentage of early successional PFTs were positively correlated with fragmentation intensity if more than half of the landscape remained undisturbed (Figure 2, left panel). For higher fragmentation intensities, both variables saturated.

The different fragmentation scenarios (random versus clustered) led to significant differences in both total and early-successional standing biomass $(P<0.001)$. The biomass fraction in late-successional PFTs varied little over the studied range of fragmentation intensity $(P<0.005)$ and not significantly between fragmentation scenarios $(P>0.1)$.

When the forest was fragmented into a few large remnants, the loss of standing biomass with increasing clearing was smallest (Figure 2). For example, in the case of a high land-use intensity $(C F=$ $90 \%$ ), 300-year-old clustered forest remnants carried $227 \mathrm{Mg} \mathrm{ha}^{-1}$ of biomass, as compared to 142 $\mathrm{Mg} \mathrm{ha}^{-1}$ in a landscape fragmented into small forest patches (crosses in Figure 2). In the latter scenario,

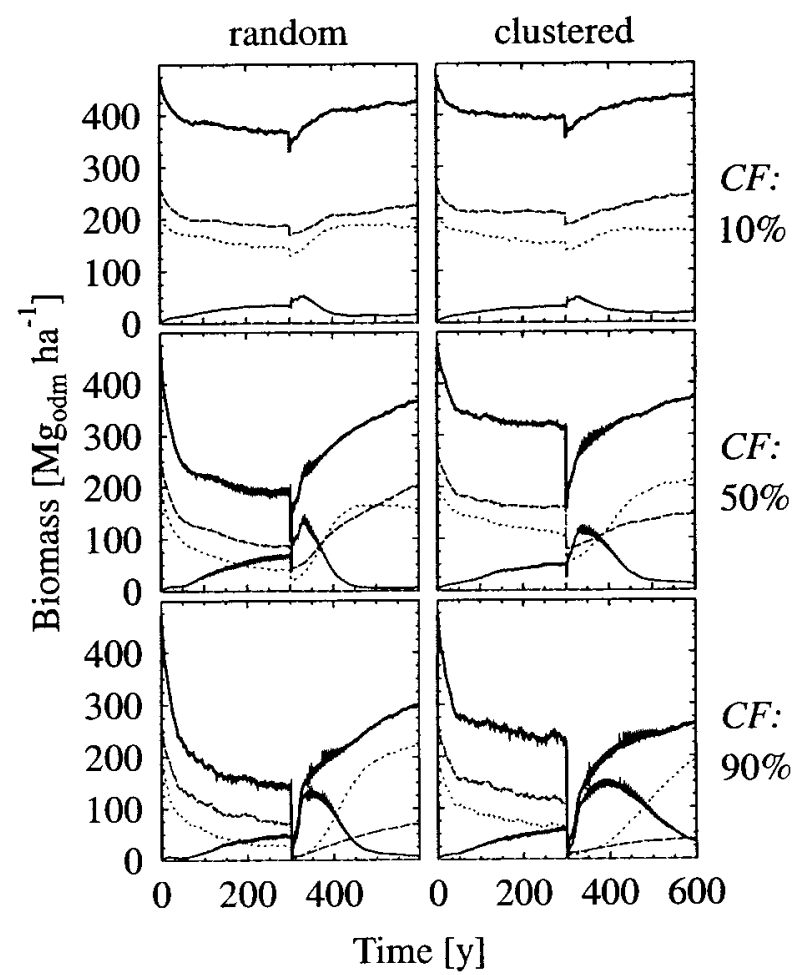

Figure 3. Time series of the aboveground biomass for two fragmentation scenarios (random and clustered) and cleared fraction $(C F=10 \%, 50 \%, 90 \%)$. Total biomass (solid bold line), biomass for early-successional species (solid line), biomass for midsuccessional species (broken dotted line), and biomass for late-successional species (broken line). Savanna species are always below $1 \mathrm{Mg} \mathrm{ha}^{-1}$ and are not shown. Land-use areas were abandoned at year 300. The biomass was only computed within the forest plots for the years $t=0-300 \mathrm{y}$ and over the whole landscape after $t=300 \mathrm{y}$; hence the apparent discontinuity in the biomass curve.

up to a third of the biomass was in early-successional PFTs, whereas in larger remnants only a fourth of the biomass was in early-successional PFTs (Figure 3). Remnants of undisturbed forest persisted at the center of the fragments (Figure 4). In the clustered scenario, more trees were free from edge effects. The fraction of patches dominated by trees taller than $30 \mathrm{~m}$ decreased from $91 \%$ (control run) to $28 \%-34 \%$ at year $300(C F=90 \%)$. Emergent trees were most sensitive to different fragmentation patterns in scenarios of medium clearing intensities (for example, when $C F=50 \%$, dominance varied between $39 \%$ and $70 \%$ ).

\section{Secondary Succession in a Forest/Nonforest Landscape Matrix}

Besides showing the impact of fragmentation on the dynamics of forest remnants, our model allows 


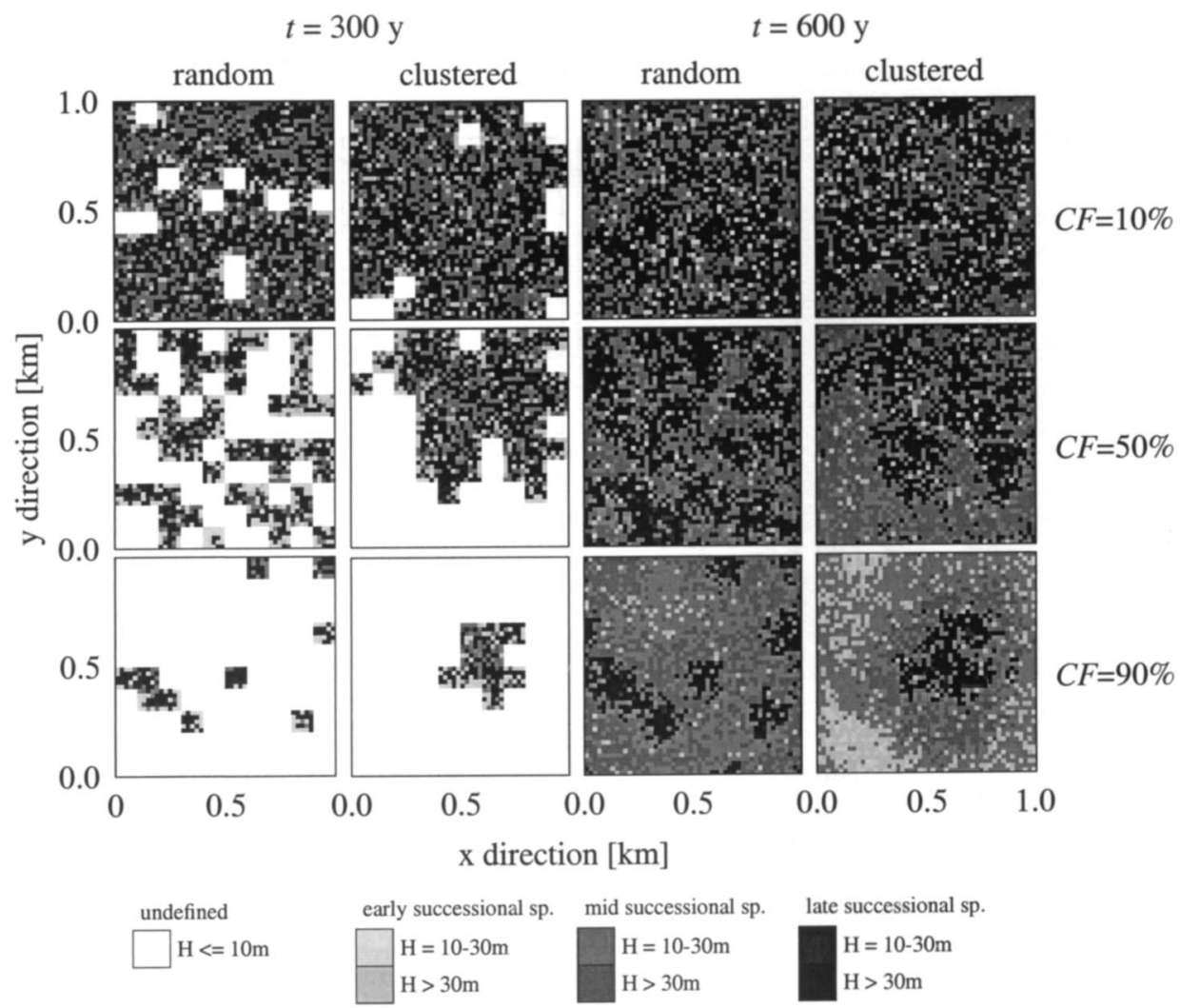

Figure 4. Spatial distribution of large trees as a function of clearing fraction $(C F)$ and of spatial clustering (random and clustered) of selected scenarios for different times $(t=300 \mathrm{y}$ : just before clear-cut areas were abandoned; $t=600 \mathrm{y}$ : after 300 years of secondary succession). Simulation area was $1 \mathrm{~km}^{2}$; each pixel corresponds to one patch $(20 \times 20 \mathrm{~m})$. Pixel color indicate the size $H$ and successional group of the largest tree of the patches according to the legend. us to investigate how clear-cut areas regenerate once they are abandoned. During the course of the secondary succession, all of the monitored variables-standing biomass, abundance of early- and late-successional species (Figure 5), and the spatial distribution of large trees (not shown)-were influenced significantly by the fraction of clear-cut land, $C F(P<0.001)$. None of the quantities monitored were significantly sensitive to the fragmentation scenario (clustered versus random, $P>0.01$ ). However, the dominance of early-successional species lasted longer in the landscape when the remaining patches were clustered (for example, 200 years in clustered versus 100 years in random with $C F=$ $90 \%$ ) (compare Figure 3). In all scenarios, the steady state in the composition of PFTs was not reached after 300 simulated succession years $(t=$ 600 y) (compare Figure 3). However, the abundance of early-successional species $(t=600 \mathrm{y})$ declined to levels close to those found in mature forests (around 7\% of standing biomass). The average abundance of early-successional species increased steadily with the cleared fraction (Figure 5).

The abundance of late-successional species was highly variable $(15 \%-56 \%)$ at year 600 and decreased as the proportion of undisturbed forest declined, regardless of the patterns of clustering (Fig- ure 5). However, the abundance of these species remained stable at about $55 \%$ in the random scenario at low fragmentation intensities $(C F \leq 50 \%)$. The total standing biomass at year 600 had still not recovered for all scenarios. Biomass was minimal for $C F=90 \%\left(264-306 \mathrm{Mg} \mathrm{ha}^{-1}\right.$, or $59 \%-68 \%$ of the control run) and was largely affected even at medium clearing intensity $(C F=50 \%, 82 \%-84 \%$ of the control run).

In a landscape with one large forest remnant (clustered scenario, $C F=90 \%$ ), it took longer to gain a composition of PFTs comparable to that of an undisturbed forest than with many small forest remnants. Patches with an abundance of large trees typical of a mature forest were fewer there $(42 \%$ versus $60 \%$ ). Again, at medium clearing intensity, differences between scenarios were negligible $(C F=$ $50 \%, 78 \%-79 \%$ ).

\section{DisCUSSION}

\section{Consequences of Forest Fragmentation}

Our study attempts to assess the long-term impact of fragmentation on the functional composition and standing biomass of tropical wet forests (Liu and Ashton 1998). We investigated scenarios that as- 


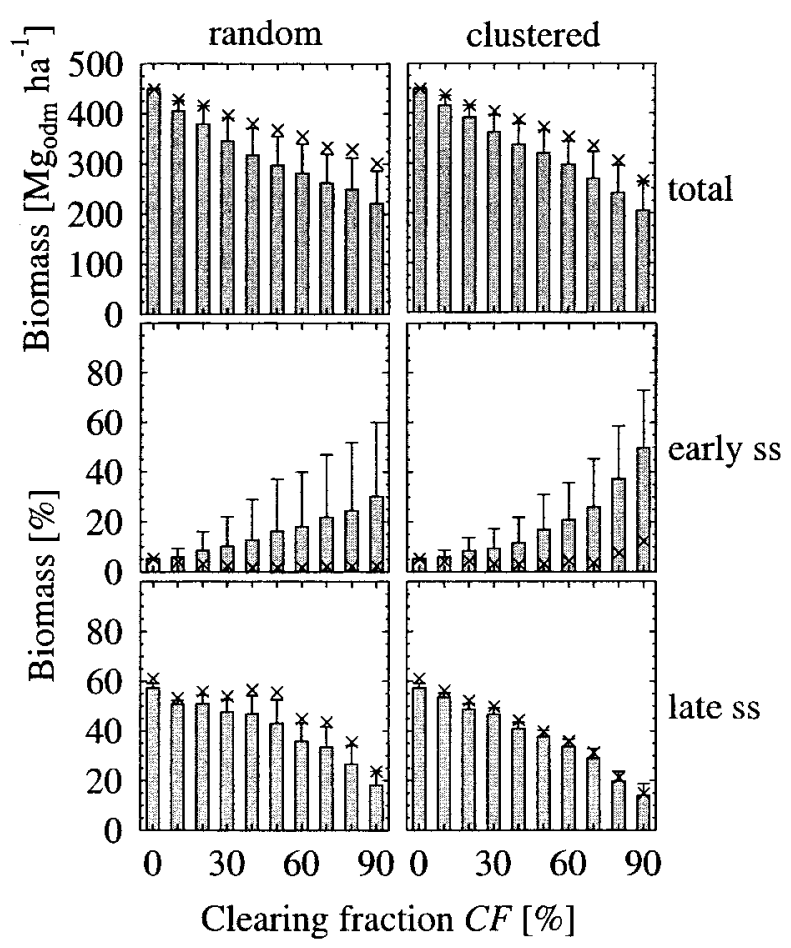

Figure 5. Regeneration and secondary succession in a fragmented landscape after cleared areas have been abandoned (same scenarios as Figure 2 but $t=301-600 \mathrm{y}$ ). Aboveground biomass as a function of cleared fraction $(C F)$ and pattern formation (random, clustered). Bars show time averages (including SD); crosses correspond to values at $t=600 \mathrm{y}$. Total biomass in organic dry matter (lst row) and fraction of early- and late-successional species (2nd and 3rd row).

sumed that increased mortality of trees near edges $(\leq 100 \mathrm{~m})$ was the major mechanism at play. Although this assumption was based on field evidence, it synthesizes the effects of several mechanisms, such as microclimate changes (higher temperature and lower moisture), higher probability of tree uprooting by wind, and direct competition with ecotone species. It would be difficult, albeit valuable, to develop a model that incorporated these as separate mechanisms.

Theory predicts that if the objective is to minimize the intensity of disturbance induced through fragmentation, then the length of forest boundaries should be minimized. However, fragmentation scenarios that minimize the edge-to-area ratio also lead to a longer delay in forest encroachment in abandoned lands. Late-successional PFTs are, in general, dispersed over shorter distances than early successional PFTs, and they need more time to reinvade abandoned land if only a few forest remnants persist (Figure 3 ). In our model, the diversity of PFTs was strongly affected by fragmentation in all the simulations. Far more early-successional PFTs were maintained in the fragmented landscape. This was expected because of the increased area with favorable conditions for establishment of this PFT. In the random model of fragmentation, the forest structure is affected only weakly for $C F \leq 50 \%$. Below this level, cleared plots are surrounded by an intact matrix that provides a microclimate and a seed rain comparable to that found in treefall gaps. In contrast, above this level, most of the fragments are isolated, and seed dispersal as well as pollination become major issues for regeneration of the forest (Aldrich and Hamrick 1998; Renner 1998). The nonlinearity of the ecosystem response around $50 \%$ of fragmentation can be interpreted theoretically (Fahrig 1992).

Our results provide a framework for interpreting several empirical findings on fragmented tropical forest landscapes. For example, Metzger (2000) recently studied a fragmented forest in Brazil to explore the relation between landscape structure and tree species richness in a tropical area suffering from deforestation. Species were grouped into PFTs similar to ours. Results showed that the influence of fragmentation was stronger for shade-tolerant, zoochorous, and barochorous species, and that shadetolerant species were particularly influenced by the connectivity of the fragments. These results are in close agreement with our study, which further provides a mechanistic interpretation of such patterns. However, like Debinski and Holt (2000), we notice that many of the conflicting results in empirical studies of forest fragmentation are likely due to experimental design issues (control of edges, spatial scale of experiments). We hope that spatially explicit, process-based models such as ours will help to reassess the design of empirical studies and to better integrate their results.

\section{Secondary Succession}

After 300 simulated years of secondary succession, a mixed landscape of forest remnants and abandoned lands had a significantly lower biomass (Figure 5) than an undisturbed forest. Thus, disturbances can have a long-lasting effect on the forest carbon pool, as has been observed in field experiments (Saldarriaga and others 1988). This effect is probably more marked in infertile soils than in fertile soils.

The regeneration after land abandonment showed that the most abundant PFTs returned to their initial abundance after at least 100 years. This transient regime was longer in clustered fragmentation scenarios (more than 200 years), due to seed- 
dispersal limitations for late-successional PFTs. This regeneration pattern showed that species composition depended on the fragmentation patterns and the dominant species group varied even after centuries for different scenarios. In a recent study in the Amazon, the species composition and richness in a 40-year-old secondary forest was significantly different from a primary forest (Ferreira and Prance 1999). In the latter, 147 species were found in an hectare, whereas the secondary forest plots supported an average of 89 species per hectare. The estimated biomasses of the primary and secondary forest were comparable (498 versus $471 \mathrm{Mg} \mathrm{ha}^{-1}$ ).

Our finding that the recovery time of fragmented tropical forests may be longer than 3 centuries merits further discussion. A forest structure comparable with the undisturbed forest is obtained only when seeds of all PFTs have dispersed into cleared areas. In our simulations, the dispersal capacity varies among PFTs. We might have underestimated longdistance seed dispersal by assuming a Gaussian seed shadow (Nathan and Muller-Landau 2000), and this might have caused the delayed establishment of various PFTs. However, even in small areas with no seed-dispersal limitation, standing biomass reaches a steady state only after about 150 simulated years, the time needed for trees to grow large. Moreover, the composition in PFTs will change for another 2 centuries. This delay depends on the growth rate of the large late-successional PFTs, which grow slowly but often reach larger sizes. In our simulation, these large trees $(40 \mathrm{~m}$ height, $100 \mathrm{~cm} \mathrm{dbh}$ ) are at least 150 years old.

Certain intense types of land use generally deplete nutrient stocks and lead to an impoverishment of the soil (Saldarriaga and others 1988; Buschbacher and others 1988). For example, forest logging has induced soil impoverishment, mainly due to decreased infiltration rates and increased runoff (Poels 1987). However, no general pattern has been discerned for this process (Saldarriaga 1986; Buschbacher and others 1988). Here we disregarded the potential influence of land use on soils and related feedbacks on the vegetation. This assumption leads to an underestimate of forest recovery time on abandoned lands. In this sense, our simulation results are conservative. We plan to incorporate such feedbacks in a forthcoming study.

\section{Limitations of the Modeling Approach}

Can we rely on the model's predictions? Such models cannot be tested carefully over such long time spans, and their relevance could be called into question. Simulation results always depend on the underlying assumptions and careful validations. How- ever, it is impossible to achieve such a validation simply because of the lack of reliable long-term chronosequences in tropical forests. Our model was validated with field data from permanent sampling plots covering 25 ha of Southeast Asian tropical rain forest over 2 decades (Köhler and others 2001). Longer time series are rarely available, and we therefore believe that confidence can be placed in our results. We, however, chose to model the fragmentation of tropical forests in French Guiana, primarily because of the availability of data and because most forest fragmentation studies in the tropics have been performed in South American forests with a similar flora. French Guiana is also a good example of a forest that has remained mostly undisturbed in recent history. Here we would like to point out a number of simplifications to our models that are of potential importance for studies of fragmented forest. These simplifications concern potential competitive release in the fragments, alteration of dispersal patterns, and accuracy of biomass estimation.

The alteration in mortality rates close to edges that were parameterized in our study based on data from a Brazilian forest (Laurance and others 1998) might be a worst case scenario. In some landscapes, vines and secondary species that grow on the edge of the forest fragments protect the remnant from abrupt microclimate changes. Thus, edge effects that are initially large may decrease over time as well as space. Invasive species may also take over abandoned pastures-for example, the babaçu palm (Orbignya phalerata Mart.) in Brazil and other vegetation elsewhere (Uhl and others 1988; Mesquita and others 2001)—and impede succession. These effects were not accounted for in the current study.

Our assumption that fragmentation does not impact seed production, seed dispersal, or seedling survival is a simplification that might, especially for high clearing intensities or scenarios that produce many small isolated forest remnants, fail. Vanishing pollinators and seed-dispersers of a closed oldgrowth forest are often replaced by invasive animals from neighboring areas, and these animals might overpredate the relict flora (Renner 1998; Curran and others 1999; Curran and Leighton 2000). Also, populations of large carnivores, which prey on herbivores and therefore stabilize food webs by preventing overgrazing, are generally at risk even within the world's largest protected areas (Redford 1992; Woodroffe and Ginsberg 1998; Robinson and others 1999; Terborgh and others 2001). These complex effects have not been taken explicitly into account in our model. Instead, we used a null model of regeneration similar to that used in other 
studies (Ribbens and others 1994; Chave 1999b). It is possible to consider regeneration rates as explicit functions of the fragmentation intensity (Kammesheidt and others 2002; P. Köhler and A. Huth unpublished). Previous sensitivity studies with our model have shown that the model results were robust to small changes in regeneration rates (Köhler 2000). An order of magnitude change in seed numbers is necessary to induce fundamental changes in the functional composition and succession time.

Biomass estimates are based on models that relate the dbh to the tree biomass (for example, see Brown 1997; Higuchi and others 1998), with limited predictive power (Brown and others 1995; Houghton and others 2001). Although it is quite difficult to assess its quality, the value predicted by our model (445 $\pm 15 \mathrm{Mg} \mathrm{ha}^{-1}$ in the control run) seems to fall in the range found in other primary tropical forest sites in the Amazon region that grow on poor soil (Ferreira and Prance 1999; Laurance and others 1999; Chave and others 2001). One additional confounding factor is that we referred to our initial site as an undisturbed primary forest. Infact, the site might have been disturbed less than a century ago; thus, the standing biomass predicted by our model at equilibrium would differ from the observed one.

Because of the uncertainties in parameterization and in site-specific distinctions, a rigorous comparison with field data-including some that are rarely measured in tropical forests (for example, respiration rates) - might allow us to gain more confidence in our model's results. Intermodel comparisons might also be a useful exercise. For example, half a dozen different global vegetation models were recently compared (Cramer and others 2001). At the forest stand level, similar comparisons have been performed for temperate forests (for example, see Bugmann and others 1996) but rarely for the tropics. Five different stand models were applied on the same site in Sabah, Malaysia, to predict the effects of several harvesting regimes (Huth 1999). Besides the similar patterns of harvest yields and species compositions, it became apparent that not only should simulation results be compared, but more importantly the underlying assumptions should be questioned more often.

\section{Toward a Multiscale Approach to Forest Fragmentation}

Forest fragmentation is likely to impact forested ecosystems over decades and perhaps even centuries. We need to assess the consequences of ecological disturbances not only qualitatively, but also with integrative and quantitative tools. Our model, however inaccurate in its details, attempts to capture the essential aspects of the ecology of fragmented tropical forests at the plot scale and to provide management guidelines at larger scales. Although our study focuses on one site, we are confident that our main findings-recovery time of several centuries for secondary successions, larger standing biomass in larger forest remnants-are relevant for other forests. The long-lasting changes in species composition have been widely ignored in conceptual models, which assess only the area potentially affected by edge effects (Laurance and Yensen 1991).

Remote sensing techniques now provide access to landscape-scale information and to chronosequences of tropical forest areas. This information has already been used to analyze the extent of tropical forest fragmentation at the landscape scale and over time (DeFries and others 2000; Helmer 2000; Cochrane 2001; Endress and Chinea 2001; Imbernon and Branthomme 2001; Sgrenzaroli and others 2002), but it must be integrated with process-based ecological approaches and socioeconomic studies to enable consistent management of the problem (Lawrence and others 1998).

\section{ACKNOWLEDGMENTS}

H. Bossel, S. DeWalt, and L. Kammesheidt provided helpful comments on the study. A. Lugo, C. Hall, W. F. Laurance, and three anonymous reviewer are acknowledged for their valuable help in shaping this and a former version of the manuscript. We thank D. Sabatier for his help in collecting the field data. P.K. received funding from the Otto Braun Foundation at the University of Kassel. J.C. was supported by grants to $S$. A. Levin from the Andrew W. Mellon Foundation and the David and Lucille Packard Foundation (grant 99-8307).

\section{REFERENCES}

Aide TM, Zimmerman JK, Herrera L, Rosario M, Serrano M 1995. Forest recovery in abandoned tropical pastures in Puerto Rico. For Eco Manage 77:77-86.

Aldrich PR, Hamrick JL. 1998. Reproductive dominance of pasture trees in a fragmented tropical mosaic. Science 281:103-5.

Botkin DB. 1993. Forest dynamics: an ecological model. Oxford (UK): Oxford University Press.

Brown IF, Martinelli LA, Thomas WW, Moreira MZ, Ferreira CAC, Victoria RA. 1995. Uncertainty in the biomass of Amazonian forests: an example from Rondônia, Brazil. For Ecol Manage 75:175-89.

Brown S. 1997. Estimating biomass and biomass change of tropical forests. A Forest Resources Assessment publication; vol 134 of Forestry Papers. Rome: Food and Agriculture Organization of the United Nations. 
Brown S, Lugo AE. 1990. Tropical secondary forests. J Trop Ecol 6:1-32.

Bugmann $\mathrm{H}$, Xiaodong $\mathrm{Y}$, Sykes MT, Martin P, Lindner M, Desanker PV, Cumming S. 1996. A comparison of forest gap models: model structure and behaviour. Clim Change 34:289313.

Bugmann HKM, Solomon AM. 2000. Explaining forest composition and biomass across multiple biogeographical regions. Ecol Appl 10:95-114.

Buschbacher R, Uhl C, Serrao EAS. 1988. Abandoned pastures in eastern Amazonia. II. Nutrient stocks in the soil and vegetation. J Ecol 76:682-99.

Chambers JC, MacMahon JA. 1994. A day in the life of a seed: movement and fates of seeds and their implications for natural and managed systems. Annu Rev Ecol Syst 25:263-92.

Chave J. 1999a. Dynamique spatio-temporelle de la forê tropicale [thesis]. Paris: Université d'Orsay,

Chave J. 1999b. Study of structural, successional and spatial pattern in tropical rain forests using TROLL, a spatially explicit forest model. Ecol Model 124:233-54.

Chave J, Riéra B, Dubois MA. 2001. Evaluation of biomass in a neotropical forest of French Guiana: spatial and temporal variability. J Trop Ecol 17:79-96.

Chave J, Wiegand K, Levin S. 2002. Spatial and biological aspects of reserve design. Environ Model Assess 7:115-122.

Clark JS, Silman M, Kern R, Macklin E, HilleRisLambers J. 1999. Seed dispersal near and far: pattern across temperate and tropical forests. Ecology 80:1475-94.

Cochrane MA. 2001 Synergistic interactions between habitat fragmentation and fire in evergreen tropical forests. Conserv Biol 15:1515-21.

Condit R, Hubbell SP, Foster RB. 1995a. Demography and harvest potential of Latin American timber species: data from a large permanent plot in Panama. J Trop For Sci 7:599-622.

Condit R, Hubbell SP, Foster RB. 1995b. Mortality rates of 205 neotropical tree and shrub species and the impact of a severe drought. Ecol Monogr 65:419-39.

Cramer W, Bondeau A, Woodward FI, Prentice IC, Betts RA, Brovkin V, Cox PM, Fisher V, Foley JA, Friend AD, and others. 2001. Global response of terrestrial ecosystem structure and function to $\mathrm{CO}_{2}$ and climate change: results from six dynamic global vegetation models. Global Change Biol 7:357-75.

Curran LM, Caniago I, Paoli GD, Astianti D, Kusneti M, Leighton M, Nirarita CE, Haeruman H. 1999. Impact of El Niño and logging on canopy tree recruitment in Borneo. Science 286: 2184-8

Curran LM, Leighton M. 2000. Vertebrate responses to spatiotemporal variation in seed production of mast-fruiting Dipterocarpaceae. Ecol Monogr 70:101-28.

da Silva JMC, Tabarelli M. 2000. Tree species impoverishment and the future flora of the Atlantic forest of northeast Brazil. Nature 404:72-4.

Debinski DM, Holt RD. 2000. A survey and overview of habitat fragmentation experiments. Conserv Biol 14:342-55.

DeFries RS, Hansen MC, Townshend JRG, Janetos AC, Loveland TR. 2000. A new global 1-km dataset of percentage tree cover derived from remote sensing. Global Change Biol 6:247-54.

Ditzer T, Glauner R, Förster M, Köhler P, Huth A. 2000. The process-based stand growth model Formix $3-\mathrm{Q}$ applied in a GIS-environment for growth and yield analysis in a tropical rain forest. Tree Physiol 20:367-81.
Endress BA, Chinea JD. 2001. Landscape patterns of tropical forest recovery in the Republic of Palau. Biotropica 33:55565.

Fahrig L. 1992. Relative importance of spatial and temporal scales in a patchy environment. Theoret Popul Biol 41:30014.

[FAO] Food and Agriculture Organization of the United Nations. 1997. State of the world's forests 1997. Rome: FAO.

Favrichon V. 1994. Classification des espèces arborées en groupes fonctionnels en vue de la réalisation d'un modèle de dynamique de peuplement en forêt guyanaise. Rev Ecol (Terre Vie) 49:379-403.

Ferreira LV, Laurance WF. 1997. Effects of forest fragmentation on mortality and damage of selected trees in central Amazonia. Conserv Biol 11:797-801.

Ferreira LV, Prance GT. 1999. Ecosystem recovery in terra firme forests after cutting and burning: a comparison on species richness, floristic composition and forest structure in the Jaú National Park, Amazonia. Bot J Linnean Soc 130:97-1 10.

Finegan B. 1996. Pattern and process in neotropical secondary rain forests: the first 100 years of succession. Trends Ecol Evolu 11:119-23.

Gascon C, Williamson GB, da Fonseca GAB. 2000. Receeding forest edges and vanishing reserves. Science 288:1356-8.

Gazel M. 1983. Croissance des arbres et productivité des peuplements en forêt dense equatoriale de Guyane. Cayenne (French Guiana): Office National des Forêts, Direction Régionale de Guyane.

Gourlet-Fleury S, Houllier F. 2000. Modelling diameter increment in a lowland evergreen rain forest in French Guiana. For Ecol Manage 131:269-89.

Graf U, Henning HP, Stange K, Wilrich PT. 1987. Formeln and Tabellen der angewandeten mathematischen Statistik. Berlin, Heidelberg, New York: Springer.

He HS, Mladenoff DJ. 1999. The effects of seed dispersal on the simulation of long-term forest landscape change. Ecosystems $2: 308-19$

Helmer EH. 2000. The landscape ecology of tropical secondary forest in montane Costa Rica. Ecosystems 3:98-1 14

Higuchi N, Santos J, Ribeiro RJ, Minette L, Biot Y. 1998. Biomassa da parte áerea da vegetação da floresta tropical úmida de terra-firme da Amazônia brasileira. Acta Amazônica 28: 153-66.

Houghton RA, Lawrence KT, Hackler JL, Brown S. 2001. The spatial distribution of forest biomass in the Brazilian Amazon: a comparison of estimates. Global Change Biol 7:731-46.

Huth A. 1999. Modellierung des Wachstums und der Nutzung von tropischem Regenwald [thesis]. Kassel (Germany): University of Kassel.

Imbernon J, Branthomme A. 2001. Characterization of landscape patterns of deforestation in tropical rain forests. Int $J$ Remote Sens 22:1753-65.

Kammesheidt L, Köhler P, Huth A. 2001. Sustainable timber harvesting in Venezuela: a modelling approach. J Appl Ecol 38:756-70

Kammesheidt L, Köhler P, Huth A. 2002. Simulating logging scenarios in secondary forest embedded in a fragmented neotropical landscape. For Ecol Manage 170:89-105.

Kato R, Tadaki Y, Ogawa H. 1978. Plant biomass and growth increment studies in Pasoh Forest. Malaysial Natl J 30:21 1-24.

Kira T. 1978. Community architecture and organic matter dy- 
namics in tropical lowland rain forests of Southeast Asia with special reference to Pasoh Forest West-Malaysia. In: Tomlinson $\mathrm{PB}$, Zimmermann $\mathrm{MH}$, editors. Tropical trees as living systems. Cambridge, (UK): Cambridge University Press. p $26-$ 30 .

Köhler P. 2000. Modelling anthropogenic impacts on the growth of tropical rain forests-using an individual-oriented forest growth model for analyses of logging and fragmentation in three case studies [thesis]. Kassel (Germany): University of Kassel. Osnabrück, (Germany): Der Andere Verlag.

Köhler P, Ditzer T, Huth A. 2000. Concepts for the aggregation of tropical tree species into functional types and the application on Sabah's lowland rain forests. J Trop Ecol 16:591-602.

Köhler P, Ditzer T, Ong RC, Huth A. 2001. Comparison of measured and modelled growth on permanent plots in Sabahs rain forests. For Ecol Manag 144:101-11.

Köhler P, Huth A. 1998. The effect of tree species grouping in tropical rain forest modelling-simulation with the individual based model Formind. Ecol Model 109:301-21.

Kramer EA. 1997. Measuring landscape changes in remnant tropical dry forests. In: Laurance WF, Bierregaard R, editors, Tropical forest remnants: ecology, management, and conservation of fragmented communities. Chicago: University of Chicago Press, p 386-99.

Kremen C, Niles J, Dalton, Daily MG, Ehrlich P, Fay J, Grewal D, Guillery RP. 2000. Economic incentives for rain forest conservation across scales. Science 288:1828-32.

Laurance WF, Bierregaard RO, editors. 1997. Tropical forest remnants: ecology, management, and conservation of fragmented communities. Chicago: University of Chicago Press.

Laurance WF, Delamonica P, Laurance SG, Vasconcelos HL, Lovejoy TE. 2000. Rainforest fragmentation kills big trees. Nature 404:836.

Laurance WF, Fearnside PM, Laurance SG, Delamonica P, Lovejoy TE, Rankin-de Merona JM, Chambers JQ, Gascon C. 1999. Relationship between soils and Amazon forest biomass: a landscape-scale study. For Ecol Manage 118:127-38.

Laurance WF, Ferreira LV, Rankin-de Merona JM, Laurance SG. 1998. Rain forest fragmentation and the dynamics of Amazonian tree communities. Ecology 79:2032-40.

Laurance WF, Yensen E. 1991. Predicting the impacts of edge effects in fragmented habitats. Biol Conserv 55:77-92.

Lawrence D, Peart DR, Leighton M. 1998. The impact of shifting cultivation on a rainforest landscape in west Kalimantan: spatial and temporal dynamics. Landscape Ecol 13:135-48.

Lescure J-P, Boulet R. 1985. Relationships between soil and vegetation in a tropical rain forest in French Guiana. Biotropica 17:155-64.

Lescure J-P, Puig H, Riéra B, Leclerc D, Beekman A, Beneteau A. 1983. La phytomasse épigée d'une forêt dense en Guyane Française. Acta Ecol Ecol Gen 4:237-51.

Liu J, Ashton PS. 1995. Individual-based simulation models for forest succession and management. For Ecol Manage 73:15775 .

Liu JG, Ashton PS. 1998. FORMOSAIC: an individual-based spatially explicit model for simulating forest dynamics in landscape mosaics. Ecol Model 106:177-200.

Mesquita R, Ickes K, Granade G, Williamson G. 2001. Alternative successional pathways in the Amazon basin. J Ecol 89: $528-37$.

Mesquita RCG, Delamonica P, Laurance WF. 1999. Effect of surrounding vegetation on edge-related tree mortality in Amazonian forest fragmentation. Biol Conserv 91:129-34.

Metzger JP. 2000. Tree functional group richness and landscape structure in a Brazilian tropical fragmented landscape. Ecol Appl 10:1147-61.

Molino JF, Sabatier D. 2001. Tree diversity in tropical rain forests: a validation of the intermediate disturbance hypothesis. Science 294:1702-4.

Moloney KE, Levin SA. 1996. The effects of disturbance architecture on landscape-level population dynamics. Ecology 77: 375-94.

Mori SA. 1989. Diversity of Lecythidaceae in the Guianas. In: Holm-Nielsen L, Nielsen I, Balslev H, editors, Tropical forests: botanical dynamics, speciation and diversity. London (UK): Academic Press, p 319-32.

Murcia C. 1995. Edge effects in fragmented forests: implications for conservation. Trends Ecol Evolu 10:58-62.

Nathan R, Muller-Landau HC. 2000. Spatial patterns of seed dispersal, their determinants and consequences for recruitment. Trends Ecol Evolu 15:278-85.

Nepstad DC, Verissimo A, Alencar A, Nobre C, Lima E, Lefebvre P, Schlesinger P, Potter C, Moutinho P, Mendoza E, and others. 1999. Large-scale impoverishment of Amazonian forests by logging and fire. Nature 398:505-8.

Oberbauer SF, Strain BS. 1984. Photosynthesis and successional status of Costa Rican rain forest trees. Photosyn Res 5:227-32.

Pacala SW, Canham CD, Saponara J, Silander JA, Kobe RK, Ribbens E. 1996. Forest models defined by field measurements: estimation error analysis and dynamics. Ecol Monogr 66:1-43.

Pelissier R, Riéra B. 1993. Dix ans de dynamique d'une forê dense humide de Guyane Francaise. Rev Ecol (Terre Vie) 48:21-33.

Phillips OL, Gentry AH. 1994. Increasing turnover through time in tropical forests. Science 263:954-58.

Poels RHL. 1987. Soils, water and nutrients in a forest ecosystem in Suriname [thesis]. Wageningen, (The Netherlands): University of Wageningen.

Poncy O, Riéra B, Larpin D, Belbenoît P, Julien M, Hoff M, Charles-Dominique P. 2000. The permanent field research station les Nouragues in the tropical rainforest of French Guiana: current projects and preliminary results on tree diversity, structure and dynamics. In: Dallmeier F, Comiskey J, editors. Forest biodiversity in North, Central and South America and the Carraibbean: research and monitoring. (Paris): UNESCO. Lancs (UK): Parthenon Publishing Group. p 398-414.

Puig H, Riéra B, Lescure JP. 1990. Phytomasse et productivité en forêt guyanaise. Bois Forêts Tropiques 220:25-32.

Purata SE. 1986. Floristic and structural changes during old-field succession in the Mexican tropics in relation to site history and species availability. J Trop Ecol 2:257-76.

Redford KH. 1992. The empty forest. BioScience 42:412-22.

Renner SS. 1998. Effects of habitat fragmentation on plant pollinator interactions in the tropics. In: Newbery DM, Brown DM, Prins HHT, editors. Dynamics of tropical forest communities. Oxford, (UK): Blackwell Science.

Ribbens E, Silander JA, Pacala SW. 1994. Seedling recruitment in forests: calibrating models to predict patterns of tree seedling dispersion. Ecology 75:1794-806.

Robinson JG, Redford KH, Bennett EL. 1999. Wildlife harvest in logged tropical forests. Science 284:595-6. 
Sabatier D, Grimaldi M, Prv́ost M-F, Guillaume J, Godron M, Dosso M, Curmi P. 1997. The influence of soil cover organization on the floristic and structural heterogeneity of a Guianan rain forest. Plant Ecol 131:81-108.

Saldarriaga JG. 1986. Recovery following shifting cultivation. Case study no. 2: a century of succession in the upper Rio Negro. In: Jordan CF, editor, Amazonian rain forests-ecosystem disturbance and recovery. New York, Berlin, Heidelberg, London, Paris, Tokyo: Springer-Verlag, p 24-33.

Saldarriaga JG, West DC, Tharp ML, Uhl C. 1988. Long-term chronosequence of forest succession in the upper Rio Negro of Colombia and Venezuela. J Ecol 76:938-58.

Saunders DA, Hobbs RJ, Margules CR. 1991. Biological consequences of ecosystem fragmentation: a review. Conserv Biol 5:18-32

Sgrenzaroli M, De Grandi GF, Eva H, Achard F. 2002. Tropical forest cover monitoring: estimates from the GRFM JERS-1 radar mosaics using wavelet zooming techniques and validation Int J Remote Sens 23:1329-55.

Shugart HH. 1998. Terrestrial ecosystems in changing environments. Cambridge (UK): Cambridge University Press.
Terborgh J, Lopez L, Nuñez PN, Rao M, Shahabuddin G, Orihuela G, Riveros M, Ascanio R, Adler GH, Lambert TD, and others. 2001. Ecological meltdown in predator-free forest fragments. Science 294:1923-6.

Uchmański J, Grimm V. 1996. Individual-based modelling in ecology: what makes the difference? Trends Ecol Evolu 11: 437-40

Uhl C, Buschbacher R, Serrao EAS. 1988. Abandoned pastures in eastern Amazonia. I: patterns of plant succession. J Ecol 76: 663-81.

van der Meer PJ, Bongers F. 1996. Patterns of tree-fall and branch-fall in a tropical rain forest in French Guiana. J Ecol 84:19-29.

van Roosmalen MGM. 1985. Fruits of the Guiana flora. Utrecht, (The Netherlands): Institute of Systematics and Botany.

Wilkie DS, Finn JT. 1988. A spatial model of land use and forest regeneration in the Ituri forest of northeastern Zaire. Ecol Model 41:307-23.

Woodroffe R, Ginsberg JR. 1998. Edge effects and the extinction of populations inside protected areas. Science 280: $2126-8$. 
Appendix. The Formind2.0 Model

Brief description of the variables, parameters, and main functions defined in the model Formind2.0.

\begin{tabular}{|c|c|}
\hline Name & Description \\
\hline & Main Variables \\
\hline$i$ & Individual tree index \\
\hline$d$ & Diameter at breast height (dbh) \\
\hline$h$ & Height \\
\hline \multirow[t]{2}{*}{$B$} & Standing aboveground biomass \\
\hline & Environmental Parameters \\
\hline$k$ & Light extinction coefficient \\
\hline$I_{0}$ & Light intensity above canopy \\
\hline$S_{\mathrm{D}}$ & Day length \\
\hline \multirow[t]{2}{*}{$S_{\mathrm{S}}$} & Length of wet/dry season \\
\hline & Establishment Parameters \\
\hline$D_{\mathrm{S}}$ & Initial diameter of seedlings \\
\hline$I_{\mathrm{S} s}$ & Minimal light intensity for germination \\
\hline$N_{\mathrm{R} s}$ & Number of seeds produced by mature trees \\
\hline$X_{\mathrm{R} s}$ & Average seed-dispersal distance \\
\hline \multirow[t]{2}{*}{$D_{\mathrm{R} h}$} & Minimal dbh of mature trees \\
\hline & Mortality Parameters \\
\hline$W$ & Probability for a dead tree to fall \\
\hline$M_{\mathrm{DO}}, M_{\mathrm{D} 1}$ & Size-dependent mortality rate $\left(M_{\mathrm{D}}=M_{\mathrm{DO}}-M_{\mathrm{Do}} / M_{\mathrm{D} 1} \cdot d\right)$ \\
\hline$M_{\mathrm{B} s, h}$ & Background mortality rate \\
\hline \multirow[t]{2}{*}{$M_{\mathrm{S} s}$} & Seed and seedling mortality rate \\
\hline & Tree Physiognomic Parameters \\
\hline$L A I_{\mathrm{M}}$ & Maximum leaf area index for a single tree \\
\hline$H_{\mathrm{M}}$ & Maximum height \\
\hline$c_{\mathrm{p}}$ & Crown length fraction \\
\hline$\tau_{\mathrm{j}}$ & Fraction of stemwood biomass in total aboveground biomass \\
\hline$h_{0}, h_{1}$ & Relationship between height and dbh $\left(h=d /\left(1 / h_{0}+d / h_{1}\right)\right)$ \\
\hline$\gamma_{0}, \gamma_{1}, \gamma_{2}$ & Relationship between form factor and $\mathrm{dbh}\left(\gamma=\gamma_{0} \cdot \exp \left(\gamma_{1} \cdot d^{\gamma_{2}}\right)\right)$ \\
\hline$f_{0}, f_{1}, f_{2}$ & Relationship between crown size and dbh $\left(d_{c}=\left(f_{0}+f_{1} \cdot d^{f 2}\right) \cdot d\right)$ \\
\hline$l_{0}, l_{1}, l_{2}$ & $\begin{array}{l}\text { Relationship between leaf area and dbh }\left(l=l_{0} \cdot d+l_{1} \cdot d^{2}+l_{2} \cdot d^{3}\right) \\
\text { Biomass Production Parameters }\end{array}$ \\
\hline$m$ & Leaf transmittance \\
\hline$g$ & Conversation factor $\mathrm{g}_{\mathrm{CO} 2}$ to $\mathrm{g}_{\mathrm{odm}}$ \\
\hline$R_{\mathrm{G}}$ & Growth respiration rate as part of biomass \\
\hline$r_{11}$ & Relationship between maintenance respiration and biomass $\left(R_{\mathrm{m}}\left(B_{i}\right)=r_{1 l} \cdot B_{i}\right)$ \\
\hline$P_{M}, \alpha$ & Photosynthetic capacity and efficiency in light response curve $P_{i}\left(I_{i}\right)=$ \\
\hline$\rho$ & Stem wood density \\
\hline$q$ & Growth limitation factor $\left(q=1-\left(1-q_{\mathrm{D}_{\mathrm{M}}}\right) \cdot\left(\frac{d_{\mathrm{i}}}{D_{M}}\right)^{2}\right)$ \\
\hline$q_{D_{\mathrm{M}}}$ & $\begin{array}{l}\text { Limitation at maximum diameter } D_{\mathrm{M}} \text { is calculated from } \mathrm{d} d\left(D_{\mathrm{M}}\right)_{\mathrm{D}_{\mathrm{M}}} \mathrm{d} t=0 \\
\text { Main Functions }\end{array}$ \\
\hline$B_{\mathrm{i}}=f\left(d_{\mathrm{i}}\right)$ & Relationship between biomass and diameter: $B_{i}=\frac{\pi}{4} d_{i}^{2} \cdot h\left(d_{i}\right) \cdot \frac{\rho \cdot \gamma\left(d_{i}\right)}{\tau}$ \\
\hline$\tilde{P}_{\mathrm{i}}=f\left(I_{\mathrm{i}}\right)$ & Photoproduction of one tree: $\tilde{P}_{i}=\frac{P_{\mathrm{M}}}{k} \ln \frac{\alpha k I_{i}+P_{\mathrm{M}}(1-m)}{\alpha k I_{i} e^{\left(-k L A I_{i}\right)}+P_{\mathrm{M}}(1-m)}$ \\
\hline$\frac{d B_{\mathrm{i}}}{\mathrm{d} t}$ & Temporal changes in biomass: $\frac{d B_{i}}{\mathrm{~d} t}=\tilde{P}_{i} \cdot q\left(1-R_{\mathrm{G}}\right)-R_{\mathrm{m}}$ \\
\hline
\end{tabular}


Parameterization of FoRmind2.0 for French Guiana. Relevant references are provided in the Methods section. The sensitivity studies (Köhler 2000; Kammesheidt and others 2001; Köhler and A. Huth unpublished) yielded the parameters of the establishment and mortality modules that produced the highest changes in the simulation results

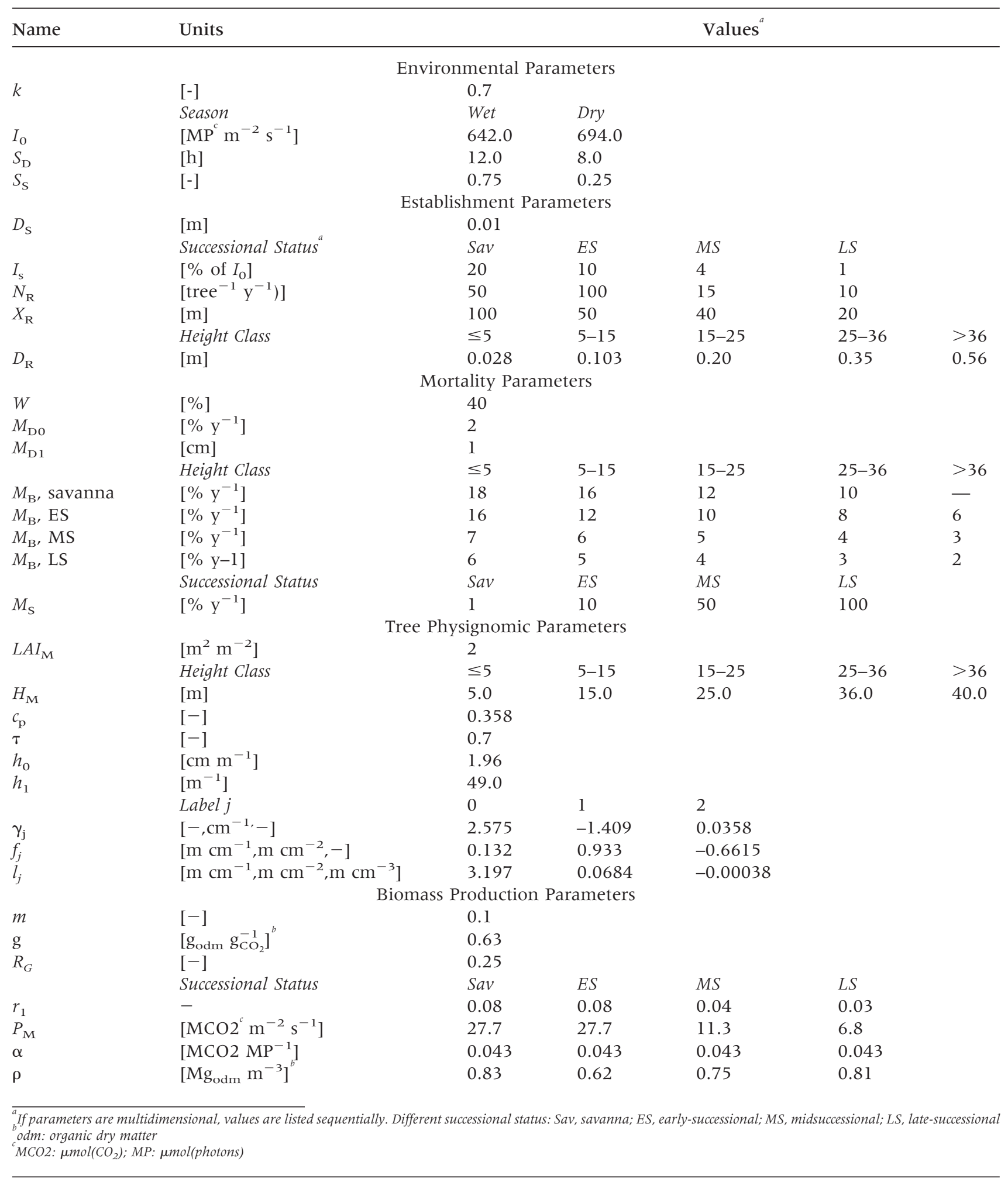

